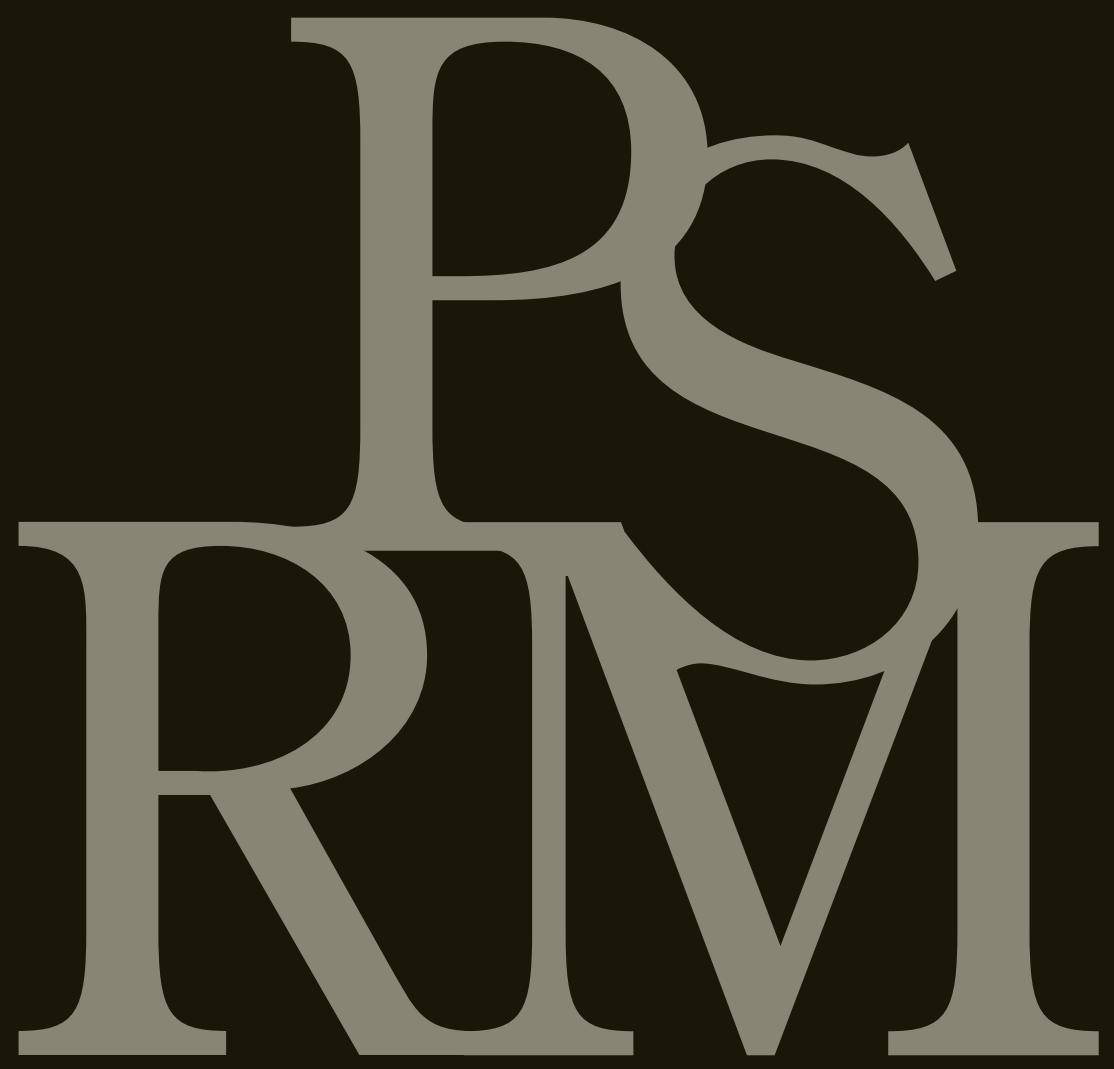

\title{
Political Science
}

\section{Research and Methods}

THE JOURNAL OF THE EUROPEAN POLITICAL SCIENCE ASSOCIATION 


\section{Political Science Research and Methods}

Political Science Research and Methods (PSRM) is a general political science journal dedicated to publishing original scholarly work of the highest quality from all subfields of political science. PSRM also welcomes work at the intersection of political science and related disciplines. Manuscripts should apply rigorous methods to empirical or theoretical problems. PSRM is the official journal of the European Political Science Association (EPSA), the organization that sets the journal's policies.

Editor-in-chief: VERA E. TROEGER, University of Warwick, UK

Associate Editors: CAMERON G. ThIES, Arizona State University, USA

KenNeth Benoit, London School of Economics, UK

SimON Hug, University of Geneva, Switzerland

Paul Kellstedt, Texas A\&M University, USA

MAssimo Moreldi, Bocconi University, Italy

DANIEl STEGMUelleR, Duke University, USA

Media Editors: MARY STEGMAIER, University of Missouri, USA

LARON WiLLIAMS, University of Missouri, USA

Data Analyst: DARINA DinTCHEVA, University of Warwick, UK

Editorial Assistants: IRINA KHOLODENKO, University of Warwick, UK

DANIEL HABERMACHER, University of Warwick, UK

\section{Editorial Board}

JAMES Alt, Harvard University, USA

Pablo Beramendi, Duke University, USA

WILLIAM T. BERNHARD, University of Illinois at Urbana-Champaign, USA

SARA BINZER-Hobolt, London School of Economics, UK

FREDERICK BOEHMKe, University of Iowa, USA

MARGit Bussman, University of Griefswald, Germany

WILLIAM R. ClaRK, Texas A\&M University, USA

Michael Colaresi, Michigan State University, USA

CATHERINE DE VRIES, University of Essex, UK

TORUN DEWAN, London School of Economics, UK

FABIo Franchino, University of Milan, Italy

Rob Franzese, University of Michigan, USA

SEAN GaIlmard, University of California, Berkeley, USA

FABRIZIO GILARDI, University of Zuriche, Switzerland

Sona Golder, Penn State University, USA

JANE GREEN, University of Manchester, UK

Jens Hainmueller, Stanford University, USA

Mark Hallerberg, Hertie School of

Governance, Germany

DOMINIK HANGARTNER, London School of Economics, UK

Jude Hays, University of Pittsburgh, USA

Havard Hegre, Peace Research Institute Oslo, Norway

SimON Hix, London School of Economics, UK

MaCARTAN Humphreys, Columbia University, USA

INDRIDI INDRIDASON, University of California,

Riverside, USA

BRAD JONES, University of California at Davis, USA

JEFF KARP, University of Sydney, Australia

MARK KAYSER, Hertie School of Governance, Germany
Thomas Koenig, University of Mannheim, Germany Michael Lewis-Beck, University of Iowa, USA

Rene Lindstaedt, University of Cardiff, UK

Philip Manow, University of Bremen, Germany

Nolan McCarty, Princeton University, USA

GaIl McElroy, Trinity College Dublin, Ireland

Nils Metternich, UCL School of Public Policy, UK

Burt Monroe, Penn State University, USA

David MyatT, London Business School, UK

AnJa Neundorf, University of Nottingham, UK

IRFAN NOORUDDIN, Georgetown University, USA

JoHn PATty, University of Chicago, USA

Elisabeth Maggie Penn, University of Chicago, USA

Thomas Pluemper, Vienna University of

Economics, Austria

Jonas Pontusson, University of Geneva, Switzerland

Sven-Oliver Proksch, University of Cologne,

Germany

STEPHANIE RickARD, London School of Economics, UK

David Rueda, Nuffield College, Oxford, UK

Frank SCHIMMELFENNIG, ETH Zurich, Switzerland

Gerald SchneIdER, University of Konstanz, Germany

Christina Schneider, University of California, San Diego, USA

Tом Scotтo, University of Strathclyde, Scotland

CURTIS SignORINO, University of Rochester, USA

Atsushi Tago, Kobe University, Japan

Stefanie Walter, University of Zurich, Switzerland

Guy Whitten, Texas A\&M University, USA

Political Science Research and Methods and all other Cambridge Journals can be found at cambridge.org/core

(C) European Political Science Association 2018

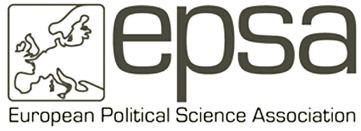

